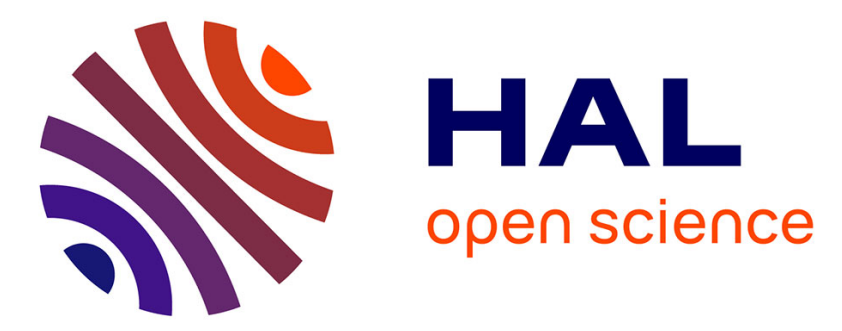

\title{
Signaling the unfolded protein response in primary brain cancers
}

Pierre-Jean Le Reste, Tony Avril, Véronique Quillien, Xavier Morandi, Eric Chevet

\section{> To cite this version:}

Pierre-Jean Le Reste, Tony Avril, Véronique Quillien, Xavier Morandi, Eric Chevet. Signaling the unfolded protein response in primary brain cancers. Brain Research, 2016, 1642, pp.59-69. 10.1016/j.brainres.2016.03.015 . hal-01295652

\section{HAL Id: hal-01295652}

\section{https://hal-univ-rennes1.archives-ouvertes.fr/hal-01295652}

Submitted on 2 Jun 2016

HAL is a multi-disciplinary open access archive for the deposit and dissemination of scientific research documents, whether they are published or not. The documents may come from teaching and research institutions in France or abroad, or from public or private research centers.
L'archive ouverte pluridisciplinaire HAL, est destinée au dépôt et à la diffusion de documents scientifiques de niveau recherche, publiés ou non, émanant des établissements d'enseignement et de recherche français ou étrangers, des laboratoires publics ou privés. 


\section{Signaling the Unfolded Protein Response in primary brain cancers}

Pierre-Jean Le Reste ${ }^{1,2}$, Tony Avril ${ }^{2,3}$, Véronique Quillien ${ }^{2,3}$, Xavier Morandi ${ }^{1}$, Eric Chevet ${ }^{2,3}$

${ }^{1}$ Department of Neurosurgery, University Hospital Pontchaillou, Rennes, France. ${ }^{2}$ Inserm ERL440 “Oncogenesis, Stress, Signaling”, Université de Rennes 1, Rennes, France. ${ }^{3}$ Centre de Lutte Contre le Cancer Eugène Marquis, Rennes, France

"Corresponding author: EC - Inserm ERL440 "Oncogenesis, Stress, Signaling", Université de Rennes 1, Centre de Lutte Contre le Cancer Eugène Marquis, Avenue de la bataille Flandres Dunkerque, 35042 Rennes, France. Tel.: +33(0)223237258. Email: eric.chevet@inserm.fr

\section{Abstract}

The Unfolded Protein Response (UPR) is an adaptive cellular program used by eukaryotic cells to cope with protein misfolding stress in the Endoplasmic Reticulum (ER). During tumor development, cancer cells are facing intrinsic (oncogene activation) and extrinsic (limiting nutrient or oxygen supply; exposure to chemotherapies) challenges, with which they must cope to survive. Primary brain tumors are relatively rare but deadly and present a significant challenge in the determination of risk factors in the population. These tumors are inherently difficult to cure because of their protected location in the brain. As such surgery, radiation and chemotherapy options carry potentially lasting patient morbidity and incomplete tumor cure. Some of these tumors, such as glioblastoma, were reported to present features of ER stress and to depend on UPR activation to sustain growth, but to date there is no clear general representation of the ER stress status in primary brain tumors. In this review, we describe the key molecular mechanisms controlling the UPR and their implication in cancers. Then we extensively review the literature reporting the status of ER stress in various primary brain tumors and discuss the potential impact of such observation on patient stratification and on the possibility of developing appropriate targeted therapies using the UPR as therapeutic target.

Keywords: Unfolded Protein Response, glioma, UPR, brain cancer, stress, endoplasmic reticulum

\section{Introduction}

Besides its functions in the regulation of calcium and lipid homeostasis, the endoplasmic reticulum (ER) is the site where elaborated machineries drive protein synthesis and quality control from their nascent forms generated within the ribosomal complexes to their productively folded state which is exported from the ER. This compartment is a complex cellular organelle that must handle approximately one third of all the proteins produced by 
the cell (Chevet et al., 2015; Dejeans et al., 2015; Hetz et al., 2015). It is a key compartment that involves an integrated network of molecules including chaperones, foldases and quality control proteins that regulates proteostasis (Balch et al., 2008). Despite this elaborated machinery, a significant proportion of proteins that transit through the ER is not properly folded and does not fulfill protein quality control standards (Schubert et al., 2000). These non-properly folded proteins are thus addressed to the ER-associated degradation (ERAD) system, leading them to the cytosol for subsequent ubiquitinylation and degradation by the proteasome (Hetz et al., 2015). In the case of an acute protein folding demand, the ER folding capacity can be overwhelmed thereby leading to a so-called "ER stress" and to the subsequent activation of an adaptive response, named the Unfolded Protein Response (UPR). The UPR i) transiently inhibits protein translation in order to limit accumulation of newly synthesized misfolded proteins in the ER thereby attenuating the protein misfolding burden; ii) increases the transcription of ER resident chaperones and foldases to increase the folding capacity of the ER; iii) augments the degradative capacity of cells to enhance protein clearance from the ER. If the stress cannot be resolved, the same signaling pathways trigger cell death (Mann and Hendershot, 2006).

Tumor development involves many different cellular functions including proliferation, migration, and differentiation that considerably increase protein synthesis and folding demand (Dejeans et al., 2015). The protein folding demand can also be increased in tumor cells because of intrinsic stresses such as oncogene expression (i.e. MYC; (Hart et al., 2013)) or aneuploidy (Dejeans et al., 2014). The ER has therefore to cope with an important protein misfolding burden to allow tumor cells to survive. In addition, tumor microenvironment often varies due to tumor rapid growth and inadequate vascularization. Therefore, tumor cells are growing in highly selective conditions such as hypoxia, nutrients deprivation and $\mathrm{pH}$ change that force them to adapt (Ma and Hendershot, 2004; Mann and Hendershot, 2006). In response to these stress conditions, tumor cells activate a range of cellular stress-response pathways including the UPR.

\section{Unfolded Protein Response signaling pathways}

ER stress is induced by a wide range of cellular perturbations as such nutrients and oxygen privation that allows cells to adapt in these restricted conditions (Hetz et al., 2015). ER stress leads to engaging the UPR that sets up several mechanisms to reduce protein synthesis, restore proper protein folding and increase the clearance of misfolded proteins from the ER. UPR activation is crucial for cell survival under challenging conditions. 
However, prolonged UPR activation leads to initiate cell death. In this section, we will first present the molecular actors of the UPR and then describe its involvement in cancers.

The three major mammalian UPR sensors that were discovered about 20 years ago are ATF6a (Activating Transcription Factor 6) (Haze et al., 1999), IRE1a (Inositol Requiring Enzyme 1) (Tirasophon et al., 1998), and PERK (PKR-like endoplasmic reticulum kinase) (Harding et al., 1999). These three sensors activate downstream signaling pathways that lead to reduce the protein misfolding, by temporarily reducing de novo protein synthesis, and increasing protein folding and clearance in the ER (Figure 1). Importantly, they are controlled by a unique protein chaperone GRP78/BiP. Under basal conditions, GRP78 constitutively binds to the luminal domains of the sensors, preventing their activation (Chevet et al., 2015; Hetz et al., 2015). When misfolded proteins accumulate in the ER, GRP78 dissociates from the sensors and strongly binds to exposed hydrophobic domains of the misfolded proteins. This leads to prime IRE1 $\alpha$ and PERK oligomerization and autophosphorylation (Bertolotti et al., 2000) and to trigger AFT6a export in the Golgi complex (Shen et al., 2002). Downstream signaling mediated by these three sensors further controls life or death decisions in cells exposed to either oncogenic or environmental (hypoxia, nutrient deprivation, $\mathrm{pH}$ ) stresses (Chevet et al., 2015).

a) AFT6 - Upon ER stress, ATF6 (also named ATF6 $\alpha$ ) is exported from the ER through the secretory pathway. ATF6 has been described to be synthesized as a naturally unstable protein and have a rapid turnover in the ER (Ninagawa et al., 2015). Under stress conditions, ATF6 is stabilized and can exit the ER through combined dissociation from BiP and action of PDIA5 (Higa et al., 2014) and its activation by proteolytic cleavage occurs in the Golgi apparatus. ATF6a cytosolic domain is released by S1P and S2P-mediated cleavage to a membrane-free form ATF6f that translocates to the nucleus and activates the transcription of genes involved in protein folding and ERAD (Chevet et al., 2015; Dejeans et al., 2015; Yamamoto et al., 2007).

b) IRE1 - IRE1 (also named IRE1 $\alpha$ ) is an ER resident transmembrane protein with serine/threonine kinase and endoribonuclease (RNase) activities at its cytoplasmic part. IRE1 dimerizes/oligomerizes in response to ER stress. Its auto-transphosphorylation induces a conformation change leading to activate its endoribonuclease domain (Hetz et al., 2015). Notably, IRE1 RNase catalyses the non-conventional splicing of XBP1 mRNA together with the RNA ligase RTCB (Jurkin et al., 2014), shifting the reading frame to translate a stable and active transcription factor XBP1s (Calfon et al., 2002; Lee et al., 2002). XBP1s activates expression of genes involved protein folding, secretion, ERAD and 
lipid synthesis (Acosta-Alvear et al., 2007; Chevet et al., 2015; Hetz et al., 2011). IRE1a RNase activity is also involved in RNA degradation (so called regulated IRE1-dependent decay - RIDD) including ER-localized mRNA, ribosomal RNA and microRNAs (Han et al., 2009; Hollien and Weissman, 2006; Hollien et al., 2009; Iwawaki et al., 2001; Lerner et al., 2012; Maurel et al., 2014; Upton et al., 2012). Importantly, the selectivity of IRE1 $\alpha$ RNase activity is highly dependent on its oligomerization state but the activation models remain still debated (Bouchecareilh et al., 2011; Ghosh et al., 2014; Han et al., 2009; Tam et al., 2014).

b) PERK - When oligomerizing upon ER stress, PERK trans-autophosphorylates and phosphorylates the translation initiation factor elF2 $\alpha$ that attenuates global protein synthesis (Chevet et al., 2015; Dejeans et al., 2015; Scheuner et al., 2001) and the transcription factor NRF2 that controls the antioxidant response (Chevet et al., 2015). Attenuation of global protein translation not only reduces the folding demand on the ER but also leads to the translational activation of the transcription factor ATF4. This transcription factor induces expression of genes involved in protein folding, amino acid metabolism, autophagy and apoptosis (Chevet et al., 2015; Hetz et al., 2015; Ye and Koumenis, 2009). ATF4 induces the transcription of the apoptosis related gene CEBP Homologous Protein CHOP (GADD153) that impacts on the control of cell death/survival outputs upon ER stress (Han et al., 2013). Moreover, these transcription factors also control the expression of the protein GADD34, which when associated to the phosphatase PP1c is responsible for the dephosphorylation of elF2 $\alpha$ and thus represents a negative feed-back mechanism in the activation of the PERK/elF2a pathway (Novoa et al., 2001).

\section{Endoplasmic reticulum stress and the Unfolded Protein Response in cancers}

Over the past decade, ER stress signaling has emerged as a major player in cancer development. The contribution of the UPR to oncogenic processes was first proposed in 2004 (Ma and Hendershot, 2004) and is now well accepted by the community. Elevated expression of UPR actors, including IRE1 $\alpha$, unspliced and spliced XBP1 and ATF6, is observed in a large range of human cancers including brain, breast, gastric, kidney, liver, lung, pancreatic and prostate cancers based on analyses of tissues sections (Table 1) (AlRawashdeh et al., 2010; Andruska et al., 2015; Epple et al., 2013; Fernandez et al., 2000; Fu et al., 2010; Fujimoto et al., 2007; Lee et al., 2006; Lee et al., 2008; Mhaidat et al., 2015; Niu et al., 2015; Pyrko et al., 2007; Scriven et al., 2009; Shuda et al., 2003; Tang et al., 2012; Tsai et al., 2013; Sheng et al., 2015). In addition, a large number of studies shows that the chaperone GRP78, the key modulator that controls ER stress mechanisms though the 
activation of the three UPR arms, is overexpressed in many cancers; and contributes to the invasion and metastasis in many human cancers (Dong et al., 2008; Firczuk et al., 2013; Hiss and Gabriels, 2009). High tumor grade and reduced survival are often associated with many tumors overexpressing GRP78 (Al-Rawashdeh et al., 2010; Fu et al., 2010; Lee et al., 2008; Niu et al., 2015; Shuda et al., 2003). In total, UPR activation is crucial for tumor growth but prolonged activation might lead to initiate apoptosis (Dejeans et al., 2015; Ma and Hendershot, 2004). Furthermore, rapid cell division, hypoxia and anti-cancer drugs generate accumulation of cell stress that leads to UPR activation (Andruska et al., 2015). Therefore, tight interconnections exist between UPR signaling pathways and major metabolic processes involved in cancer development and progression (Manie et al., 2014), and examples of these connections will be now presented.

a) Cancer initiation - This is particularly well illustrated in the normal gastrointestinal tract that displays a heterogeneous distribution of UPR components among intestinal cell populations. Indeed, GRP78 expression is lower in intestinal stem cells but is higher in more differentiated transit amplifying cells (Heijmans et al., 2013). Interestingly, activation of the PERK/elF2 $\alpha$ axis is involved in the loss of stemness in intestinal stem cells (ISC), cells from which most colorectal cancers (CRC) derive (Vermeulen and Snippert, 2014) suggesting that ER stress has a role during cancer initiation in the gastrointestinal tract (Dejeans et al., 2015). In a colitis-associated cancer model, the IRE1 $\alpha$ pathway appears to be an important mediator of ER stress-induced ISC expansion. Indeed, XBP1 loss in epithelial cells results in an increase of cancer initiation due to intestinal stem cell hyper-proliferation (Dejeans et al., 2015).

b) Tumor aggressiveness and dormancy - Cancer cell dormancy is one of the adaptive mechanisms to tumor environment including chemotherapy, nutrient starvation and in vivo microenvironmental challenges. ATF6 $\alpha$ is implicated in the regulation of tumor cell dormancy (Schewe and Aguirre-Ghiso, 2008). Indeed, ATF6a is identified as a survival factor for quiescent but not proliferative squamous carcinoma cells (Schewe and Aguirre-Ghiso, 2008). The PERK-eIF2 $\alpha$ pathway is also critical for tumor cell dormancy and contributes to anti-cancer drug resistance (Fels and Koumenis, 2006). In triple negative breast cancers (TNBC), a link between UPR-mediated IRE1 $\alpha$ activation and hypoxia-inducible factor HIF-1 $\alpha$ contributes to TNBC aggressiveness (Chen et al., 2014). Indeed, the IRE1 $\alpha$ arm and in particular the splicing of XBP1 mRNA are constitutively activated in TNBC, thereby conferring these tumor cells with higher aggressiveness due to XBP1s-mediated HIF-1a activation (Chen et al., 2014). In glioblastoma (GBM), the highest grade of primary brain 
cancers, tumor invasion is a mark of aggressiveness. Interestingly, the extracellular matrix protein SPARC, involved in tumor invasion, is regulated by IRE1 $\alpha$ endoribonuclease activity (Dejeans et al., 2012).

c) UPR-mediated 'secretory switch' in cancer cells - Cancer hallmarks imply the acute secretory reorientation of cancer cells that leads to impact on their cellular functions and their interaction with the tumor microenvironment (Dejeans et al., 2015; Hanahan and Weinberg, 2011). For instance, change in secreted extracellular matrix (ECM) components and matrix metalloproteases (MMP) affects tumor dissemination and invasion (Bissell and Hines, 2011; Leung and Brugge, 2012). Modulation of cytokines/chemokines secretion also triggers cancer cell proliferation and tumor angiogenesis (Dejeans et al., 2015). As an unavoidable organelle for secreted and transmembrane proteins, the ER has a critical impact on this 'secretory switch'. Furthermore the UPR, activated during cancer development, also affects this phenomenon. Epithelial to mesenchymal transition (EMT) enables carcinoma cells to acquire key malignant traits such as migratory and invasion properties, induces stem cell properties and drug resistance (Dejeans et al., 2015). EMT is fine-tuned by specific transcription factors that repress epithelial markers and up-regulate mesenchymal markers accompanied by morphologic changes. Expression of these transcription factors is often associated with UPR activation. For instance, in breast tumors, increased expression of XBP1s is observed in metastatic tumors, regulated by the EMTinducer SNAIL. TWIST overexpression also correlates with PERK constitutive activation (Feng et al., 2014). The UPR-induced 'secretory switch' might contribute to this phenomenon. Indeed UPR involvement in EMT was recently shown in breast cancers (Del Vecchio et al., 2014; Feng et al., 2014; Ulianich et al., 2008). In mammary epithelial cells, overexpression of Serpin B3, a serine/cysteine protease inhibitor, induces chronic UPR that in turn activates NF-KB and leads to IL-6 production, thus resulting in an EMT-like phenotype (Sheshadri et al., 2014). EMT is also associated with an important change in ECM architecture, allowing tumor cell invasion. Interestingly, inhibition of PERK-elF2 $\alpha$ signaling attenuates cell ability to migrate and to form tumor spheres, thereby indicating that PERK might be involved in EMT-dependent cell malignancy. In GBM, dominant negative form of IRE1a triggers a mesenchymal drift, characterized by modulation of the expression of extracellular matrix, angiogenesis, and inflammatory chemokines (Auf et al., 2010a).

d) Tumor angiogenesis and metabolism - As part of the 'secretory switch', the UPR also affects the expression of pro-angiogenic factors that contribute to tumor angiogenesis. In an IRE1a-dominant negative GBM model, IRE1a is involved in positive regulation of the 
secretion of factors such as VEGF-A, IL-1 $\beta$ and IL-6 (Auf et al., 2010a; Drogat et al., 2007) and the cleavage of the mRNA coding for the circadian gene PERIOD1 (Pluquet et al., 2013a). This pathway represents an important mediator of GBM infiltration that supports to tumor angiogenesis (Auf et al., 2010a). The PERK-ATF4 branch up-regulates VEGF to induce angiogenesis in response to hypoxic stress (Blais et al., 2006; Chevet et al., 2015; Dejeans et al., 2015; Manie et al., 2014). Due to glucose deprivation, cancer cells have to adapt their cellular metabolism and UPR directly contributes to this phenomenon. Indeed, XBP1s triggers the expression of key hexosamine biosynthetic pathway (HBP) enzymes that convert glucose to UDP-acetylglucosamine (UDP-GlcNac) (Denzel et al., 2014; Wang et al., 2014), a subtrate for protein O- and N-glycosylation thus improving proteotasis. In TNBC cancer cells, XBP1s actively promotes glucose uptake by cancer cells via HIF-1 $\alpha$ activation that up-regulates several glycolytic proteins including glucose transporter 1 (GLUT1) (Ferrer et al., 2014).

To activate additional energy supplies, cancer cells have also the capacity to trigger ER stress dependent autophagic pathways. The PERK/eIF2a/ATF4 pathway is activated upon hypoxia in tumor cells and protects these cells from environmental damages through autophagy via LC3B and ATG5 (Bi et al., 2005; Blais et al., 2004; Rouschop et al., 2010). Similarly, autophagy is induced by the binding of TRAF2 to IRE1 $\alpha$ leading to downstream activation of JNK (Ogata et al., 2006). In addition, genetic inactivation of XBP1 switches the protein homeostasis (proteostasis) network toward autophagy up-regulation (Hetz et al., 2009). These studies illustrate a highly dynamic network that controls cancer cells' ability to adapt and resist to environmental stresses through UPR-dependent mechanisms (Chevet et al., 2015).

\section{ER stress in primary brain cancers}

An analysis of the literature revealed that a significant number of primary brain cancers elicited the features of ER stress either at ultrastructural or molecular levels (Table 2). We review these tumor characteristics below.

a) Glioblastoma - Glioblastoma multiform (GBM) is the most common primary brain tumor. GBMs represent the highest degree of malignancy of astrocytic lineage neoplasms (WHO Grade IV). Treatment modalities usually include maximal resection, radiotherapy, and chemotherapy with the common use of temozolomide as first-line treatment (Stupp et al., 2005). However, GBM remain incurable and median survival remains close to 18 months (Pallud et al., 2015). As most malignant and fast-growing tumors, GBM cells are exposed to 
high cellular stress levels due to inadequate blood supply, hypoxia, nutrient deprivation, as well as to immune reactions and to various therapeutic treatments. There is strong evidence towards a major involvement of UPR signaling in GBM oncogenesis and resistance to treatments. As such, work from our group has clearly established the contribution of IRE1 $\alpha$ signaling in GBM (Chevet et al., 2015) and particularly in tumor growth ((Auf et al., 2013), neo-angiogenesis (Auf et al., 2010b; Drogat et al., 2007; Pluquet et al., 2013b) and migration/invasion properties (Dejeans et al., 2012; Jabouille et al., 2015)). Moreover, the PERK pathway has also been involved in the control of GBM cells metabolism (Hou et al., 2015) and response to treatment (Hamed et al., 2010; Yacoub et al., 2010). Finally, the ATF6 pathway was recently reported to contribute to GBM resistance to radiotherapy (Dadey et al., 2015) (Figure 2).

b) Lower-grade tumors - Lower-grade astrocytomas (WHO Grade I/II) constitute a heterogeneous group of tumors mostly represented by oligodendrogliomas and astrocytomas, the classification and prognostic indicators of which being completely transformed by molecular diagnosis (Weller et al., 2015). They usually show a slower evolution than that of GBM, but despite treatments their natural history will ultimately lead to a grade IV tumor. Oligodendrogliomas only show infrequent structural signs of ER involvement (Liberski, 1996). The expression of chaperone protein GRP78 has been found to be low in oligodendrogliomas and low-grade astrocytomas (Lee et al., 2008). To our knowledge no other specific signaling pattern of UPR has been assessed in these tumors. However, these elements should be considered again looking at all ER stress sensors and effectors in the light of recent classification changes. As such we investigated the expression of PERK, IRE1 and ATF6 in normal brain, astrocytes and gliomas (grade II to IV). This unveiled that PERK and IRE1 expression globally increased in glioblastoma and did not vary much in lower grade tumors (Figure 3).

c) Meningioma - Meningiomas are frequent intracranial tumors arising from the cap cells of the arachnoid. Most meningiomas are slow-growing and benign tumors (WHO grade I), but some of them can show invasive characteristics (WHO grade II) and even anaplastic features (WHO grade III) (Cimino, 2015). While the gold standard treatment of grade I meningiomas treatment is surgery, higher grades might benefit from complementary treatments such as radiotherapy (Hasan et al., 2015). However, no consensual chemotherapy has still been adopted (Moazzam et al., 2013). Ultrastructural studies showed the presence of closely arranged lamellae of ER in grade I meningiomas, and abundant rough ER in chordoid meningiomas (WHO Grade II) (Couce et al., 2000; Tani and Higashi, 
1973). To our knowledge, no study addressed the specific issue of ER stress in meningiomas. One genetic analysis of different grades of meningioma suggested a role of ATF6 in meningioma aggressiveness (Iglesias Gómez and Mosquera Orgueira, 2014). Moreover, TXNDC16, an antigen closely associated with the presence of a meningioma, is an ER associated glycoprotein (Harz et al., 2014). A role of ER stress in meningiomas aggressiveness is indirectly supported by the use of mifepristone in uncontrollable tumors. This progesterone inhibitor is known to induce ER stress through the activation of ATF6 and PERK leading to elF2 $\alpha$ phosphorylation, even if ATF4 and XBP1s remain unchanged (Dioufa et al., 2010). However, the clinical results of mifepristone seem mitigated (Cossu et al., 2015; Ji et al., 2015). Further studies are needed to assess the role of ER stress in anaplastic meningiomas, but the rarity of such lesions limits wide cohort analysis.

d) Medulloblastoma - Medulloblastomas (MB) belong to the heterogeneous group of primitive neurectodermal tumors. They represent the most common brain tumor in childhood, and mostly arise from the cerebellum with involvement of the fourth ventricle and brainstem. Usual treatment comprises at least surgical removal, and additional therapeutics according to multimodal risk stratification (Martin et al., 2014). Four molecular MB subtypes have been described thus far (WNT-, SHH-, groups 3- and 4- MB), showing different clinical courses and response to treatments (Northcott et al., 2011; Northcott et al., 2012). Several studies highlighted genetic abnormalities linking MB oncogenesis with ER stress and the UPR. One of the main features of WNT-MB is the activation of the WNT/beta-catenin pathway. CTNNB1 mutations have been shown to lead to high nuclear beta-catenin accumulation, whereas non-mutated cells exhibit low or absent nuclear expression, or cytoplasmic staining of this protein (Eberhart et al., 2000). In other malignancies such as multiple myeloma, the accumulation of beta-catenin induces ER stress signaling through the phosphorylation of elF2 $\alpha$ and the subsequent expression of CHOP and p21 (Raab et al., 2009), alternatively in BCR-ABL1 positive CML this occurs through the cytoplasmic accumulation of beta-catenin. As such one can postulate that beta-catenin induced UPR might be linked to the triggering of EMT, which in turn could be related to MB metastasis (Nasir et al., 2014). Sonic hedgehog $(\mathrm{SHH})$-type MBs harbor constitutive activation of the Hedgehog $(\mathrm{HH})$ pathway. Some nonbrain tumors models showed that increased $\mathrm{HH}$ signaling activated ER stress sensors and UPR (Marada et al., 2013). The key role of ER stress in SHH MB is supported by the fact that PERK activation facilitates cerebellar dysplasia and SHH-type MB formation in interferon-gamma activated mouse, this occurring through induction of $\mathrm{HH}$ pathways (Lin et al., 2011). PERK activation also facilitates cell migration and angiogenesis by inducing 
VEGF secretion (Jamison et al., 2015). In addition, group 3-MBs show a particularly high expression of MYC and MYCN. It has been shown that MYC amplification leads to Rasinduced down regulation of the BIP/PERK/NRF2 and elF2 $\alpha / A T F 4 / A T F 3$ pathways (YaariStark et al., 2010). As such one can postulate again that ER stress pathways in MB might constitute potentially druggable targets, even if the heterogeneity of MB leads to various signaling processes. Apart from genetic aberrations, exogenous factors might lead to MB formation. Indeed an oncogenetic role of the JC virus has been suggested in the pathogenesis of various brain tumor types, including MB, even if this remains controversial (Muñoz-Mármol et al., 2006). Experimental data support that the T-Antigen of this polyomavirus participates to the triggering of pro-apopoptic pathways through chronic ER stress response (Macaluso et al., 2012). Thus, despite having various roles in the different subtypes of MB, it seems that ER stress signaling is involved in many key features of this tumor.

e) Pineal Tumor - The pineal body is a small gland located at the posterior part of the third ventricle. Its main endocrine role lies in the secretion of melatonin, a hormone involved in chronobiological rhythms. Pineal tumors constitute a very diverse group of tumors, accounting for less than $1 \%$ of primary brain tumors. Pineal parenchymal tumors are mainly represented by the slow-growing pinealocytomas (WHO Grade II), the more aggressive pinealoblastomas (WHO Grade IV), and mixed-type tumors. Germinal tumors are frequent in this location. Other histological varieties include rare tumors such as papillary tumors (WHO Grade II/III) and chordoid gliomas (WHO Grade II) (De Girolami et al., 2008). To our knowledge, no specific work has yet addressed the relation between pineal tumors and ER stress. Only ultrastructural studies showed signs of ER enlargement in pinealoblastomas, pinealocytomas and papillary tumors (Jouvet et al., 2003; Kline et al., 1979; Tabuchi et al., 1973). However, special reference should be done about the role of melatonin in ER stress mechanisms. Melatonin is known to be an inducer of antioxidant pathways, and harbors itself ROS scavenger properties. There is evidence of its potential role in ER stressmediated apoptosis and sensitization to ER stress inductors (Fernández et al., 2015). Therefore, it could be hypothesized that melatonin can play a role in pineal parenchymal tumors through ER stress, as these tumors conserve a capacity of melatonin secretion (Fevre-Montange et al., 2008). This however needs further specific studies.

f) Choroid plexus tumor - Choroid plexus (CP) are the anatomical structures secreting the cerebrospinal fluid within the ventricles, formed by a fine maze of fenestrated capillaries. CP tumors are rare entities, representing less than $1 \%$ of all primary brain 
tumors; they are more frequently found in children (Rickert and Paulus, 2001). Two main histopathological types are encountered: the CP papilloma, a benign neuroectodermal tumor (WHO Grade I), and CP carcinoma (WHO Grade III), which exhibits a worse prognosis. Surgical treatment is the mainstay of the cure of these tumors, however radiation therapy and chemotherapy may be used in case of surgical remnant, recurrence or leptomeningeal dissemination (Sun et al., 2014). Considering the rarity of such lesions, only very few studies focused on ER stress. Ultrastructural studies showed moderate to elevated intracellular enlargement of the ER in CP carcinomas, thus indicating indirectly a potential induction of ER stress (Anguilar et al., 1983; McComb and Burger, 1983). Another study compared the expression of ER calcium ATPase-type pumps (SERCA enzymes) in normal CP cells, CP papilloma and carcinoma (Ait-Ghezali et al., 2014). Their expression levels correlate with the activation of ER stress (Højmann Larsen et al., 2001). Normal CP epithelial cells showed a strong expression of SERCA3, which was decreased in CP papillomas and absent in CP carcinomas. Besides being an interesting biomarker for diagnosis, SERCA dysregulation enlightens ER stress as a potential key feature of CP oncogenesis.

g) Other primary tumors - All other primary brain tumors have been mainly studied on an ultrastructural level, such as hemangioblastomas (Ho, 1987), myxopapillary ependymomas (Ho, 1990) or subependymal giant cell astrocytomas (Liberski, 1998). To our knowledge, no signaling analysis in regards to UPR has been made about other intracranial primary tumors.

\section{Conclusions and therapeutic perspectives}

From the above observations, it appears that ER-dependent mechanisms, most likely involving proteostasis control pathways play key roles in the pathogenesis and treatment sensitivity of numerous primary brain tumors. In order to better define the functional roles of these pathways in these types of tumors we need to characterize the activation status of ER proteostasis control signaling pathways in larger cohorts of human tumors to be able to propose an ER-based classification. Although these analyses could be performed on paraffin-embeded tumor samples, one might also consider identifying ER stress markers in the cerebrospinal fluid. Although very few studies have described such biomarkers in cases of neurodegenerative diseases, yet their association with primary brain tumors remains to be proven. Moreover, the characterization of UPR signaling in those tumors might provide novel therapeutic strategies either used individually or in combination with existing therapeutics, even if such strategy would require the identification of potent biomarkers to test treatment 
efficacy. As such, molecules that target IRE1 or PERK catalytic activities (Hetz et al., 2013) could be anticipated to be useful in tumors either dependent on those activities to survive or exhibiting high endogenous activity such as glioblastoma. Moreover, the combination of such targeted therapies with traditional therapeutic protocols such as the Stupp protocol for GBM might reveal efficient to improve therapeutic outcomes for this dismal disease.

\section{Acknowledgements}

We apologize to colleagues whose work was not cited in this article due to space limitation. This work was supported by grants from Institut National du Cancer (INCa) and La Ligue Contre le Cancer to EC.

\section{References}

Acosta-Alvear, D., Zhou, Y., Blais, A., Tsikitis, M., Lents, N.H., Arias, C., Lennon, C.J., Kluger, Y., Dynlacht, B.D., 2007. XBP1 controls diverse cell type- and conditionspecific transcriptional regulatory networks. Mol Cell. 27, 53-66.

Ait-Ghezali, L., Arbabian, A., Jeibmann, A., Hasselblatt, M., Hallaert, G.G., Van den Broecke, C., Gray, F., Brouland, J.-P., Varin-Blank, N., Papp, B., 2014. Loss of endoplasmic reticulum calcium pump expression in choroid plexus tumours. Neuropathology and Applied Neurobiology. 40, 726-735.

Al-Rawashdeh, F.Y., Scriven, P., Cameron, I.C., Vergani, P.V., Wyld, L., 2010. Unfolded protein response activation contributes to chemoresistance in hepatocellular carcinoma. Eur J Gastroenterol Hepatol. 22, 1099-105.

Andruska, N., Zheng, X., Yang, X., Helferich, W.G., Shapiro, D.J., 2015. Anticipatory estrogen activation of the unfolded protein response is linked to cell proliferation and poor survival in estrogen receptor alpha-positive breast cancer. Oncogene. 34, 37609.

Anguilar, D., Martín, J.M., Aneiros, J., Arjona, V., Lara, J.L., Nogales, F., 1983. The fine structure of choroid plexus carcinoma. Histopathology. 7, 939-946.

Auf, G., Jabouille, A., Guerit, S., Pineau, R., Delugin, M., Bouchecareilh, M., Magnin, N., Favereaux, A., Maitre, M., Gaiser, T., von Deimling, A., Czabanka, M., Vajkoczy, P., Chevet, E., Bikfalvi, A., Moenner, M., 2010a. Inositol-requiring enzyme 1alpha is a key regulator of angiogenesis and invasion in malignant glioma. Proc Natl Acad Sci U S A. $107,15553-8$.

Auf, G., Jabouille, A., Guérit, S., Pineau, R., Delugin, M., Bouchecareilh, M., Magnin, N., Favereaux, A., Maitre, M., Gaiser, T., von Deimling, A., Czabanka, M., Vajkoczy, P., Chevet, E., Bikfalvi, A., Moenner, M., 2010b. Inositol-requiring enzyme 1alpha is a key regulator of angiogenesis and invasion in malignant glioma. Proceedings of the National Academy of Sciences of the United States of America. 107, 15553-15558.

Auf, G., Jabouille, A., Delugin, M., Guérit, S., Pineau, R., North, S., Platonova, N., Maitre, M., Favereaux, A., Vajkoczy, P., Seno, M., Bikfalvi, A., Minchenko, D., Minchenko, O., Moenner, M., 2013. High epiregulin expression in human U87 glioma cells relies on IRE1 $\alpha$ and promotes autocrine growth through EGF receptor. BMC cancer. 13, 597.

Balch, W.E., Morimoto, R.I., Dillin, A., Kelly, J.W., 2008. Adapting proteostasis for disease intervention. Science. 319, 916-9. 
Bertolotti, A., Zhang, Y., Hendershot, L.M., Harding, H.P., Ron, D., 2000. Dynamic interaction of BiP and ER stress transducers in the unfolded-protein response. Nat Cell Biol. 2, 326-32.

Bi, M., Naczki, C., Koritzinsky, M., Fels, D., Blais, J., Hu, N., Harding, H., Novoa, I., Varia, M., Raleigh, J., Scheuner, D., Kaufman, R.J., Bell, J., Ron, D., Wouters, B.G., Koumenis, C., 2005. ER stress-regulated translation increases tolerance to extreme hypoxia and promotes tumor growth. EMBO J. 24, 3470-81.

Bissell, M.J., Hines, W.C., 2011. Why don't we get more cancer? A proposed role of the microenvironment in restraining cancer progression. Nat Med. 17, 320-9.

Blais, J.D., Filipenko, V., Bi, M., Harding, H.P., Ron, D., Koumenis, C., Wouters, B.G., Bell, J.C., 2004. Activating transcription factor 4 is translationally regulated by hypoxic stress. Mol Cell Biol. 24, 7469-82.

Blais, J.D., Addison, C.L., Edge, R., Falls, T., Zhao, H., Wary, K., Koumenis, C., Harding, H.P., Ron, D., Holcik, M., Bell, J.C., 2006. Perk-dependent translational regulation promotes tumor cell adaptation and angiogenesis in response to hypoxic stress. Mol Cell Biol. 26, 9517-32.

Bouchecareilh, M., Higa, A., Fribourg, S., Moenner, M., Chevet, E., 2011. Peptides derived from the bifunctional kinase/RNase enzyme IRE1alpha modulate IRE1alpha activity and protect cells from endoplasmic reticulum stress. FASEB J. 25, 3115-29.

Calfon, M., Zeng, H., Urano, F., Till, J.H., Hubbard, S.R., Harding, H.P., Clark, S.G., Ron, D., 2002. IRE1 couples endoplasmic reticulum load to secretory capacity by processing the XBP-1 mRNA. Nature. 415, 92-6.

Chen, X., Iliopoulos, D., Zhang, Q., Tang, Q., Greenblatt, M.B., Hatziapostolou, M., Lim, E., Tam, W.L., Ni, M., Chen, Y., Mai, J., Shen, H., Hu, D.Z., Adoro, S., Hu, B., Song, M., Tan, C., Landis, M.D., Ferrari, M., Shin, S.J., Brown, M., Chang, J.C., Liu, X.S., Glimcher, L.H., 2014. XBP1 promotes triple-negative breast cancer by controlling the HIF1alpha pathway. Nature. 508, 103-7.

Chevet, E., Hetz, C., Samali, A., 2015. Endoplasmic Reticulum Stress-Activated Cell Reprogramming in Oncogenesis. Cancer Discov. 5, 586-597.

Choi, J.W., Schroeder, M.A., Sarkaria, J.N., Bram, R.J., 2014. Cyclophilin B supports Myc and mutant p53-dependent survival of glioblastoma multiforme cells. Cancer Research. 74, 484-496.

Cimino, P.J., 2015. Malignant progression to anaplastic meningioma: Neuropathology, molecular pathology, and experimental models. Experimental and Molecular Pathology. 99, 354-359.

Cossu, G., Levivier, M., Daniel, R.T., Messerer, M., 2015. The Role of Mifepristone in Meningiomas Management: A Systematic Review of the Literature. BioMed Research International. 2015, 267831.

Couce, M.E., Aker, F.V., Scheithauer, B.W., 2000. Chordoid meningioma: a clinicopathologic study of 42 cases. The American Journal of Surgical Pathology. 24, 899-905.

Dadey, D.Y., Kapoor, V., Khudanyan, A., Urano, F., Kim, A.H., Thotala, D., Hallahan, D.E., 2015. The ATF6 pathway of the ER stress response contributes to enhanced viability in glioblastoma. Oncotarget.

De Girolami, U., Fèvre-Montange, M., Seilhean, D., Jouvet, A., 2008. Pathology of tumors of the pineal region. Revue Neurologique. 164, 882-895.

Dejeans, N., Pluquet, O., Lhomond, S., Grise, F., Bouchecareilh, M., Juin, A., MeynardCadars, M., Bidaud-Meynard, A., Gentil, C., Moreau, V., Saltel, F., Chevet, E., 2012. Autocrine control of glioma cells adhesion and migration through IRE1alphamediated cleavage of SPARC mRNA. J Cell Sci. 125, 4278-87. 
Dejeans, N., Manie, S., Hetz, C., Bard, F., Hupp, T., Agostinis, P., Samali, A., Chevet, E., 2014. Addicted to secrete - novel concepts and targets in cancer therapy. Trends Mol Med. 20, 242-50.

Dejeans, N., Barroso, K., Fernandez-Zapico, M.E., Samali, A., Chevet, E., 2015. Novel roles of the unfolded protein response in the control of tumor development and aggressiveness. Semin Cancer Biol. 33, 67-73.

Del Vecchio, C.A., Feng, Y., Sokol, E.S., Tillman, E.J., Sanduja, S., Reinhardt, F., Gupta, P.B., 2014. De-differentiation confers multidrug resistance via noncanonical PERKNrf2 signaling. PLoS Biol. 12, e1001945.

Denzel, M.S., Storm, N.J., Gutschmidt, A., Baddi, R., Hinze, Y., Jarosch, E., Sommer, T., Hoppe, T., Antebi, A., 2014. Hexosamine pathway metabolites enhance protein quality control and prolong life. Cell. 156, 1167-78.

Dioufa, N., Kassi, E., Papavassiliou, A.G., Kiaris, H., 2010. Atypical induction of the unfolded protein response by mifepristone. Endocrine. 38, 167-73.

Dong, W., Zhang, Y., Yan, M., Liu, H., Chen, Z., Zhu, P., 2008. Upregulation of 78-kDa glucose-regulated protein in macrophages in peripheral joints of active ankylosing spondylitis. Scand J Rheumatol. 37, 427-34.

Drogat, B., Auguste, P., Nguyen, D.T., Bouchecareilh, M., Pineau, R., Nalbantoglu, J., Kaufman, R.J., Chevet, E., Bikfalvi, A., Moenner, M., 2007. IRE1 signaling is essential for ischemia-induced vascular endothelial growth factor-A expression and contributes to angiogenesis and tumor growth in vivo. Cancer Res. 67, 6700-7.

Eberhart, C.G., Tihan, T., Burger, P.C., 2000. Nuclear localization and mutation of betacatenin in medulloblastomas. Journal of Neuropathology and Experimental Neurology. 59, 333-337.

Epple, L.M., Dodd, R.D., Merz, A.L., Dechkovskaia, A.M., Herring, M., Winston, B.A., Lencioni, A.M., Russell, R.L., Madsen, H., Nega, M., Dusto, N.L., White, J., Bigner, D.D., Nicchitta, C.V., Serkova, N.J., Graner, M.W., 2013. Induction of the unfolded protein response drives enhanced metabolism and chemoresistance in glioma cells. PLoS One. 8, e73267.

Fels, D.R., Koumenis, C., 2006. The PERK/elF2alpha/ATF4 module of the UPR in hypoxia resistance and tumor growth. Cancer Biol Ther. 5, 723-8.

Feng, Y.X., Sokol, E.S., Del Vecchio, C.A., Sanduja, S., Claessen, J.H., Proia, T.A., Jin, D.X., Reinhardt, F., Ploegh, H.L., Wang, Q., Gupta, P.B., 2014. Epithelial-to-mesenchymal transition activates PERK-elF2alpha and sensitizes cells to endoplasmic reticulum stress. Cancer Discov. 4, 702-15.

Fernández, A., Ordóñez, R., Reiter, R.J., González-Gallego, J., Mauriz, J.L., 2015. Melatonin and endoplasmic reticulum stress: relation to autophagy and apoptosis. Journal of Pineal Research. 59, 292-307.

Fernandez, P.M., Tabbara, S.O., Jacobs, L.K., Manning, F.C., Tsangaris, T.N., Schwartz, A.M., Kennedy, K.A., Patierno, S.R., 2000. Overexpression of the glucose-regulated stress gene GRP78 in malignant but not benign human breast lesions. Breast Cancer Res Treat. 59, 15-26.

Ferrer, C.M., Lynch, T.P., Sodi, V.L., Falcone, J.N., Schwab, L.P., Peacock, D.L., Vocadlo, D.J., Seagroves, T.N., Reginato, M.J., 2014. O-GlcNAcylation regulates cancer metabolism and survival stress signaling via regulation of the HIF-1 pathway. Mol Cell. 54, 820-31.

Fevre-Montange, M., Champier, J., Szathmari, A., Brisson, C., Reboul, A., Mottolese, C., Fauchon, F., Claustrat, B., Jouvet, A., 2008. Histological features and expression of enzymes implicated in melatonin synthesis in pineal parenchymal tumours and in cultured tumoural pineal cells. Neuropathology and Applied Neurobiology. 34, 296305. 
Firczuk, M., Gabrysiak, M., Barankiewicz, J., Domagala, A., Nowis, D., Kujawa, M., Jankowska-Steifer, E., Wachowska, M., Glodkowska-Mrowka, E., Korsak, B., Winiarska, M., Golab, J., 2013. GRP78-targeting subtilase cytotoxin sensitizes cancer cells to photodynamic therapy. Cell Death Dis. 4, e741.

Fu, W., Wu, X., Li, J., Mo, Z., Yang, Z., Huang, W., Ding, Q., 2010. Upregulation of GRP78 in renal cell carcinoma and its significance. Urology. 75, 603-7.

Fujimoto, T., Yoshimatsu, K., Watanabe, K., Yokomizo, H., Otani, T., Matsumoto, A., Osawa, G., Onda, M., Ogawa, K., 2007. Overexpression of human X-box binding protein 1 (XBP-1) in colorectal adenomas and adenocarcinomas. Anticancer Res. 27, 127-31.

Ghosh, R., Wang, L., Wang, E.S., Perera, B.G., Igbaria, A., Morita, S., Prado, K., Thamsen, M., Caswell, D., Macias, H., Weiberth, K.F., Gliedt, M.J., Alavi, M.V., Hari, S.B., Mitra, A.K., Bhhatarai, B., Schurer, S.C., Snapp, E.L., Gould, D.B., German, M.S., Backes, B.J., Maly, D.J., Oakes, S.A., Papa, F.R., 2014. Allosteric inhibition of the IRE1alpha RNase preserves cell viability and function during endoplasmic reticulum stress. Cell. 158, 534-48.

Hamed, H.A., Yacoub, A., Park, M.A., Eulitt, P., Sarkar, D., Dimitrie, I.P., Chen, C.S., Grant, S., Curiel, D.T., Fisher, P.B., Dent, P., 2010. OSU-03012 enhances Ad.7-induced GBM cell killing via ER stress and autophagy and by decreasing expression of mitochondrial protective proteins. Cancer Biol Ther. 9, 526-36.

Han, D., Lerner, A.G., Vande Walle, L., Upton, J.-P., Xu, W., Hagen, A., Backes, B.J., Oakes, S.A., Papa, F.R., 2009. IRE1alpha kinase activation modes control alternate endoribonuclease outputs to determine divergent cell fates. Cell. 138, 562-75.

Han, J., Back, S.H., Hur, J., Lin, Y.H., Gildersleeve, R., Shan, J., Yuan, C.L., Krokowski, D., Wang, S., Hatzoglou, M., Kilberg, M.S., Sartor, M.A., Kaufman, R.J., 2013. ERstress-induced transcriptional regulation increases protein synthesis leading to cell death. Nat Cell Biol. 15, 481-90.

Hanahan, D., Weinberg, R.A., 2011. Hallmarks of cancer: the next generation. Cell. 144, 646-674.

Harding, H.P., Zhang, Y., Ron, D., 1999. Protein translation and folding are coupled by an endoplasmic-reticulum-resident kinase. Nature. 397, 271-4.

Hart, L.S., Cunningham, J.T., Datta, T., Dey, S., Tameire, F., Lehman, S.L., Quu, B., Zhang, H., Cerniglia, G., Bi, M., Li, Y., Gao, Y., Liu, H., Li, C., Maity, A., Thomas-Tikhonenko, A., Perl, A.E., Koong, A., Fuchs, S.Y., Diehl, J.A., Mills, I.G., Ruggero, D., Koumenis, C., 2013. ER stress-mediated autophagy promotes Myc-dependent transformation and tumor growth. J Clin Invest. 122, 4621-34.

Harz, C., Ludwig, N., Lang, S., Werner, T.V., Galata, V., Backes, C., Schmitt, K., Nickels, R., Krause, E., Jung, M., Rettig, J., Keller, A., Menger, M., Zimmermann, R., Meese, E., 2014. Secretion and immunogenicity of the meningioma-associated antigen TXNDC16. Journal of Immunology (Baltimore, Md.: 1950). 193, 3146-3154.

Hasan, S., Young, M., Albert, T., Shah, A.H., Okoye, C., Bregy, A., Lo, S.S., Ishkanian, F., Komotar, R.J., 2015. The role of adjuvant radiotherapy after gross total resection of atypical meningiomas. World Neurosurgery. 83, 808-815.

Haze, K., Yoshida, H., Yanagi, H., Yura, T., Mori, K., 1999. Mammalian transcription factor ATF6 is synthesized as a transmembrane protein and activated by proteolysis in response to endoplasmic reticulum stress. Mol Biol Cell. 10, 3787-99.

Heijmans, J., van Lidth de Jeude, J.F., Koo, B.K., Rosekrans, S.L., Wielenga, M.C., van de Wetering, M., Ferrante, M., Lee, A.S., Onderwater, J.J., Paton, J.C., Paton, A.W., Mommaas, A.M., Kodach, L.L., Hardwick, J.C., Hommes, D.W., Clevers, H., Muncan, V., van den Brink, G.R., 2013. ER stress causes rapid loss of intestinal epithelial stemness through activation of the unfolded protein response. Cell Rep. 3, 1128-39. 
Hetz, C., Thielen, P., Matus, S., Nassif, M., Court, F., Kiffin, R., Martinez, G., Cuervo, A.M., Brown, R.H., Glimcher, L.H., 2009. XBP-1 deficiency in the nervous system protects against amyotrophic lateral sclerosis by increasing autophagy. Genes Dev. 23, 2294306.

Hetz, C., Martinon, F., Rodriguez, D., Glimcher, L.H., 2011. The unfolded protein response: integrating stress signals through the stress sensor IRE1alpha. Physiol Rev. 91, 1219-43.

Hetz, C., Chevet, E., Harding, H.P., 2013. Targeting the unfolded protein response in disease. Nat Rev Drug Discov. 12, 703-19.

Hetz, C., Chevet, E., Oakes, S.A., 2015. Proteostasis control by the unfolded protein response. Nat Cell Biol. 17, 829-38.

Higa, A., Taouji, S., Lhomond, S., Jensen, D., Fernandez-Zapico, M.E., Simpson, J.C., Pasquet, J.M., Schekman, R., Chevet, E., 2014. Endoplasmic reticulum stressactivated transcription factor ATF6alpha requires the disulfide isomerase PDIA5 to modulate chemoresistance. Mol Cell Biol. 34, 1839-49.

Hiss, D.C., Gabriels, G.A., 2009. Implications of endoplasmic reticulum stress, the unfolded protein response and apoptosis for molecular cancer therapy. Part II: targeting cell cycle events, caspases, NF-kappaB and the proteasome. Expert Opin Drug Discov. 4, 907-21.

Ho, K.L., 1987. Ultrastructure of cerebellar capillary hemangioblastoma. VI. Concentric lamellar bodies of endoplasmic reticulum in stromal cells. Acta Neuropathologica. 74, 345-353.

Ho, K.L., 1990. Microtubular aggregates within rough endoplasmic reticulum in myxopapillary ependymoma of the filum terminale. Archives of Pathology \& Laboratory Medicine. 114, 956-960.

Højmann Larsen, A., Frandsen, A., Treiman, M., 2001. Upregulation of the SERCA-type $\mathrm{Ca} 2+$ pump activity in response to endoplasmic reticulum stress in PC12 cells. BMC Biochemistry. 2, 4.

Hollien, J., Weissman, J.S., 2006. Decay of endoplasmic reticulum-localized mRNAs during the unfolded protein response. Science. 313, 104-7.

Hollien, J., Lin, J.H., Li, H., Stevens, N., Walter, P., Weissman, J.S., 2009. Regulated Ire1dependent decay of messenger RNAs in mammalian cells. J Cell Biol. 186, 323-31.

Hou, X., Liu, Y., Liu, H., Chen, X., Liu, M., Che, H., Guo, F., Wang, C., Zhang, D., Wu, J., Shen, C., Li, C., Peng, F., Bi, Y., Yang, Z., Yang, G., Ai, J., Gao, X., Zhao, S., 2015. PERK silence inhibits glioma cell growth under low glucose stress by blockage of $p$ AKT and subsequent HK2's mitochondria translocation. Sci Rep. 5, 9065.

Iglesias Gómez, J.C., Mosquera Orgueira, A., 2014. An integrative analysis of meningioma tumors reveals the determinant genes and pathways of malignant transformation. Frontiers in Oncology. 4, 147.

Iwawaki, T., Hosoda, A., Okuda, T., Kamigori, Y., Nomura-Furuwatari, C., Kimata, Y., Tsuru, A., Kohno, K., 2001. Translational control by the ER transmembrane kinase/ribonuclease IRE1 under ER stress. Nat Cell Biol. 3, 158-64.

Jabouille, A., Delugin, M., Pineau, R., Dubrac, A., Soulet, F., Lhomond, S., Pallares-Lupon, N., Prats, H., Bikfalvi, A., Chevet, E., Touriol, C., Moenner, M., 2015. Glioblastoma invasion and cooption depend on IRE1 $\alpha$ endoribonuclease activity. Oncotarget. 6, 24922-24934.

Jamison, S., Lin, Y., Lin, W., 2015. Pancreatic endoplasmic reticulum kinase activation promotes medulloblastoma cell migration and invasion through induction of vascular endothelial growth factor A. PloS One. 10, e0120252.

Ji, Y., Rankin, C., Grunberg, S., Sherrod, A.E., Ahmadi, J., Townsend, J.J., Feun, L.G., Fredericks, R.K., Russell, C.A., Kabbinavar, F.F., Stelzer, K.J., Schott, A., 
Verschraegen, C., 2015. Double-Blind Phase III Randomized Trial of the Antiprogestin Agent Mifepristone in the Treatment of Unresectable Meningioma: SWOG S9005. Journal of Clinical Oncology: Official Journal of the American Society of Clinical Oncology. 33, 4093-4098.

Johnson, G.G., White, M.C., Wu, J.-H., Vallejo, M., Grimaldi, M., 2014. The deadly connection between endoplasmic reticulum, $\mathrm{Ca} 2+$, protein synthesis, and the endoplasmic reticulum stress response in malignant glioma cells. Neuro-Oncology. $16,1086-1099$

Jouvet, A., Fauchon, F., Liberski, P., Saint-Pierre, G., Didier-Bazes, M., Heitzmann, A., Delisle, M.-B., Biassette, H.A., Vincent, S., Mikol, J., Streichenberger, N., Ahboucha, S., Brisson, C., Belin, M.-F., Fèvre-Montange, M., 2003. Papillary tumor of the pineal region. The American Journal of Surgical Pathology. 27, 505-512.

Jurkin, J., Henkel, T., Nielsen, A.F., Minnich, M., Popow, J., Kaufmann, T., Heindl, K., Hoffmann, T., Busslinger, M., Martinez, J., 2014. The mammalian tRNA ligase complex mediates splicing of XBP1 mRNA and controls antibody secretion in plasma cells. EMBO J.

Kline, K.T., Damjanov, I., Katz, S.M., Schmidek, H., 1979. Pineoblastoma: an electron microscopic study. Cancer. 44, 1692-1699.

Le Mercier, M., Lefranc, F., Mijatovic, T., Debeir, O., Haibe-Kains, B., Bontempi, G., Decaestecker, C., Kiss, R., Mathieu, V., 2008a. Evidence of galectin-1 involvement in glioma chemoresistance. Toxicol Appl Pharmacol. 229, 172-83.

Le Mercier, M., Mathieu, V., Haibe-Kains, B., Bontempi, G., Mijatovic, T., Decaestecker, C., Kiss, R., Lefranc, F., 2008b. Knocking down galectin 1 in human hs683 glioblastoma cells impairs both angiogenesis and endoplasmic reticulum stress responses. Journal of Neuropathology and Experimental Neurology. 67, 456-469.

Lee, E., Nichols, P., Spicer, D., Groshen, S., Yu, M.C., Lee, A.S., 2006. GRP78 as a novel predictor of responsiveness to chemotherapy in breast cancer. Cancer Res. 66, 7849-53.

Lee, H.K., Xiang, C., Cazacu, S., Finniss, S., Kazimirsky, G., Lemke, N., Lehman, N.L., Rempel, S.A., Mikkelsen, T., Brodie, C., 2008. GRP78 is overexpressed in glioblastomas and regulates glioma cell growth and apoptosis. Neuro Oncol. 10, 23643.

Lee, K., Tirasophon, W., Shen, X., Michalak, M., Prywes, R., Okada, T., Yoshida, H., Mori, K., Kaufman, R.J., 2002. IRE1-mediated unconventional mRNA splicing and S2Pmediated ATF6 cleavage merge to regulate XBP1 in signaling the unfolded protein response. Genes Dev. 16, 452-66.

Lerner, A.G., Upton, J.P., Praveen, P.V., Ghosh, R., Nakagawa, Y., Igbaria, A., Shen, S., Nguyen, V., Backes, B.J., Heiman, M., Heintz, N., Greengard, P., Hui, S., Tang, Q., Trusina, A., Oakes, S.A., Papa, F.R., 2012. IRE1alpha induces thioredoxin-interacting protein to activate the NLRP3 inflammasome and promote programmed cell death under irremediable ER stress. Cell Metab. 16, 250-64.

Leung, C.T., Brugge, J.S., 2012. Outgrowth of single oncogene-expressing cells from suppressive epithelial environments. Nature. 482, 410-3.

Liberski, P.P., 1996. The ultrastructure of oligodendroglioma: personal experience and the review of the literature. Folia Neuropathologica / Association of Polish Neuropathologists and Medical Research Centre, Polish Academy of Sciences. 34, 206-211.

Liberski, P.P., 1998. The ultrastructure of glial tumors of astrocytic lineage: a review. Folia Neuropathologica / Association of Polish Neuropathologists and Medical Research Centre, Polish Academy of Sciences. 36, 161-177. 
Lin, W., Lin, Y., Li, J., Harding, H.P., Ron, D., Jamison, S., 2011. A deregulated integrated stress response promotes interferon- $\gamma$-induced medulloblastoma. Journal of Neuroscience Research. 89, 1586-1595.

Ma, Y., Hendershot, L.M., 2004. The role of the unfolded protein response in tumour development: friend or foe? Nat Rev Cancer. 4, 966-77.

Macaluso, M., Caracciolo, V., Rizzo, V., Sun, A., Montanari, M., Russo, G., Bellipanni, G., Khalili, K., Giordano, A., 2012. Integrating role of T antigen, Rb2/p130, CTCF and BORIS in mediating non-canonical endoplasmic reticulum-dependent death pathways triggered by chronic ER stress in mouse medulloblastoma. Cell Cycle (Georgetown, Tex.). 11, 1841-1850.

Manie, S.N., Lebeau, J., Chevet, E., 2014. Cellular mechanisms of endoplasmic reticulum stress signaling in health and disease. 3. Orchestrating the unfolded protein response in oncogenesis: an update. Am J Physiol Cell Physiol. 307, C901-7.

Mann, M.J., Hendershot, L.M., 2006. UPR activation alters chemosensitivity of tumor cells. Cancer Biol Ther. 5, 736-40.

Marada, S., Stewart, D.P., Bodeen, W.J., Han, Y.-G., Ogden, S.K., 2013. The unfolded protein response selectively targets active smoothened mutants. Molecular and Cellular Biology. 33, 2375-2387.

Martin, A.M., Raabe, E., Eberhart, C., Cohen, K.J., 2014. Management of pediatric and adult patients with medulloblastoma. Current Treatment Options in Oncology. 15, 581-594.

Maurel, M., Chevet, E., Tavernier, J., Gerlo, S., 2014. Getting RIDD of RNA: IRE1 in cell fate regulation. Trends Biochem Sci. 39, 245-54.

McComb, R.D., Burger, P.C., 1983. Choroid plexus carcinoma. Report of a case with immunohistochemical and ultrastructural observations. Cancer. 51, 470-475.

Mhaidat, N.M., Alzoubi, K.H., Almomani, N., Khabour, O.F., 2015. Expression of glucose regulated protein 78 (GRP78) determines colorectal cancer response to chemotherapy. Cancer Biomark. 15, 197-203.

Moazzam, A.A., Wagle, N., Zada, G., 2013. Recent developments in chemotherapy for meningiomas: a review. Neurosurgical Focus. 35, E18.

Muñoz-Mármol, A.M., Mola, G., Ruiz-Larroya, T., Fernández-Vasalo, A., Vela, E., Mate, J.L., Ariza, A., 2006. Rarity of JC virus DNA sequences and early proteins in human gliomas and medulloblastomas: the controversial role of JC virus in human neurooncogenesis. Neuropathology and Applied Neurobiology. 32, 131-140.

Nasir, A., Othman, R., Storer, L., Onion, D., Lourdasamy, A., Grabowska, A., Coyle, B., 2014. BM-23Twist1 EXPRESSION CONFIRMS THE ROLE OF AN EMT-LIKE PROCESS IN MEDULLOBLASTOMA METASTASIS. Neuro-Oncology. 16, v37-v37.

Ninagawa, S., Okada, T., Sumitomo, Y., Horimoto, S., Sugimoto, T., Ishikawa, T., Takeda, S., Yamamoto, T., Suzuki, T., Kamiya, Y., Kato, K., Mori, K., 2015. Forcible destruction of severely misfolded mammalian glycoproteins by the non-glycoprotein ERAD pathway. J Cell Biol. 211, 775-84.

Niu, Z., Wang, M., Zhou, L., Yao, L., Liao, Q., Zhao, Y., 2015. Elevated GRP78 expression is associated with poor prognosis in patients with pancreatic cancer. Sci Rep. 5, 16067.

Northcott, P.A., Korshunov, A., Witt, H., Hielscher, T., Eberhart, C.G., Mack, S., Bouffet, E., Clifford, S.C., Hawkins, C.E., French, P., Rutka, J.T., Pfister, S., Taylor, M.D., 2011. Medulloblastoma comprises four distinct molecular variants. Journal of Clinical Oncology: Official Journal of the American Society of Clinical Oncology. 29, 14081414.

Northcott, P.A., Korshunov, A., Pfister, S.M., Taylor, M.D., 2012. The clinical implications of medulloblastoma subgroups. Nature Reviews. Neurology. 8, 340-351. 
Novoa, I., Zeng, H., Harding, H.P., Ron, D., 2001. Feedback inhibition of the unfolded protein response by GADD34-mediated dephosphorylation of elF2alpha. J Cell Biol. 153, 1011-22.

Ogata, M., Hino, S., Saito, A., Morikawa, K., Kondo, S., Kanemoto, S., Murakami, T., Taniguchi, M., Tanii, I., Yoshinaga, K., Shiosaka, S., Hammarback, J.A., Urano, F., Imaizumi, K., 2006. Autophagy is activated for cell survival after endoplasmic reticulum stress. Mol Cell Biol. 26, 9220-31.

Ozawa, K., Tsukamoto, Y., Hori, O., Kitao, Y., Yanagi, H., Stern, D.M., Ogawa, S., 2001. Regulation of tumor angiogenesis by oxygen-regulated protein 150, an inducible endoplasmic reticulum chaperone. Cancer Res. 61, 4206-13.

Pallud, J., Audureau, E., Noel, G., Corns, R., Lechapt-Zalcman, E., Duntze, J., Pavlov, V., Guyotat, J., Hieu, P.D., Le Reste, P.-J., Faillot, T., Litre, C.-F., Desse, N., Petit, A., Emery, E., Voirin, J., Peltier, J., Caire, F., Vignes, J.-R., Barat, J.-L., Langlois, O., Dezamis, E., Parraga, E., Zanello, M., Nader, E., Lefranc, M., Bauchet, L., Devaux, B., Menei, P., Metellus, P., Neurochirurgie, C.d.N.-O.o.t.S.F.d., 2015. Long-term results of carmustine wafer implantation for newly diagnosed glioblastomas: a controlled propensity-matched analysis of a French multicenter cohort. NeuroOncology. 17, 1609-1619.

Pluquet, O., Dejeans, N., Bouchecareilh, M., Lhomond, S., Pineau, R., Higa, A., Delugin, M., Combe, C., Loriot, S., Cubel, G., Dugot-Senant, N., Vital, A., Loiseau, H., Gosline, S.J., Taouji, S., Hallett, M., Sarkaria, J.N., Anderson, K., Wu, W., Rodriguez, F.J., Rosenbaum, J., Saltel, F., Fernandez-Zapico, M.E., Chevet, E., 2013a. Posttranscriptional regulation of PER1 underlies the oncogenic function of IREalpha. Cancer Res. 73, 4732-43.

Pluquet, O., Dejeans, N., Bouchecareilh, M., Lhomond, S., Pineau, R., Higa, A., Delugin, M., Combe, C., Loriot, S., Cubel, G., Dugot-Senant, N., Vital, A., Loiseau, H., Gosline, S.J.C., Taouji, S., Hallett, M., Sarkaria, J.N., Anderson, K., Wu, W., Rodriguez, F.J., Rosenbaum, J., Saltel, F., Fernandez-Zapico, M.E., Chevet, E., 2013b. Posttranscriptional regulation of PER1 underlies the oncogenic function of IREa. Cancer Research. 73, 4732-4743.

Proulx-Bonneau, S., Pratt, J., Annabi, B., 2011. A role for MT1-MMP as a cell death sensor/effector through the regulation of endoplasmic reticulum stress in U87 glioblastoma cells. Journal of Neuro-Oncology. 104, 33-43.

Pyrko, P., Schonthal, A.H., Hofman, F.M., Chen, T.C., Lee, A.S., 2007. The unfolded protein response regulator GRP78/BiP as a novel target for increasing chemosensitivity in malignant gliomas. Cancer Res. 67, 9809-16.

Quick, Q.A., Faison, M.O., 2012. CHOP and caspase 3 induction underlie glioblastoma cell death in response to endoplasmic reticulum stress. Experimental and Therapeutic Medicine. 3, 487-492.

Raab, M.S., Breitkreutz, I., Tonon, G., Zhang, J., Hayden, P.J., Nguyen, T., Fruehauf, J.H., Lin, B.K., Chauhan, D., Hideshima, T., Munshi, N.C., Anderson, K.C., Podar, K., 2009. Targeting PKC: a novel role for beta-catenin in ER stress and apoptotic signaling. Blood. 113, 1513-1521.

Rickert, C.H., Paulus, W., 2001. Tumors of the choroid plexus. Microscopy Research and Technique. 52, 104-111.

Rouschop, K.M., van den Beucken, T., Dubois, L., Niessen, H., Bussink, J., Savelkouls, K., Keulers, T., Mujcic, H., Landuyt, W., Voncken, J.W., Lambin, P., van der Kogel, A.J., Koritzinsky, M., Wouters, B.G., 2010. The unfolded protein response protects human tumor cells during hypoxia through regulation of the autophagy genes MAP1LC3B and ATG5. J Clin Invest. 120, 127-41. 
Scheuner, D., Song, B., McEwen, E., Liu, C., Laybutt, R., Gillespie, P., Saunders, T., BonnerWeir, S., Kaufman, R.J., 2001. Translational control is required for the unfolded protein response and in vivo glucose homeostasis. Mol Cell. 7, 1165-76.

Schewe, D.M., Aguirre-Ghiso, J.A., 2008. ATF6alpha-Rheb-mTOR signaling promotes survival of dormant tumor cells in vivo. Proc Natl Acad Sci U S A. 105, 10519-24.

Schubert, U., Anton, L.C., Gibbs, J., Norbury, C.C., Yewdell, J.W., Bennink, J.R., 2000. Rapid degradation of a large fraction of newly synthesized proteins by proteasomes. Nature. 404, 770-4.

Scriven, P., Coulson, S., Haines, R., Balasubramanian, S., Cross, S., Wyld, L., 2009. Activation and clinical significance of the unfolded protein response in breast cancer. Br J Cancer. 101, 1692-8.

Shen, J., Chen, X., Hendershot, L., Prywes, R., 2002. ER stress regulation of ATF6 localization by dissociation of BiP/GRP78 binding and unmasking of Golgi localization signals. Dev Cell. 3, 99-111.

Sheng, X., Arnoldussen, Y.J., Storm, M., Tesikova, M., Nenseth, H.Z., Zhao, S., Fazli, L., Rennie, P., Risberg, B., Waehre, H., Danielsen, H., Mills, I.G., Jin, Y., Hotamisligil, G., Saatcioglu, F., 2015. Divergent androgen regulation of unfolded protein response pathways drives prostate cancer. EMBO Mol Med. 7, 788-801.

Sheshadri, N., Catanzaro, J.M., Bott, A.J., Sun, Y., Ullman, E., Chen, E.I., Pan, J.A., Wu, S., Crawford, H.C., Zhang, J., Zong, W.X., 2014. SCCA1/SERPINB3 promotes oncogenesis and epithelial-mesenchymal transition via the unfolded protein response and IL6 signaling. Cancer Res. 74, 6318-29.

Shuda, M., Kondoh, N., Imazeki, N., Tanaka, K., Okada, T., Mori, K., Hada, A., Arai, M., Wakatsuki, T., Matsubara, O., Yamamoto, N., Yamamoto, M., 2003. Activation of the ATF6, XBP1 and grp78 genes in human hepatocellular carcinoma: a possible involvement of the ER stress pathway in hepatocarcinogenesis. J Hepatol. 38, 60514.

Stupp, R., Mason, W.P., van den Bent, M.J., Weller, M., Fisher, B., Taphoorn, M.J.B., Belanger, K., Brandes, A.A., Marosi, C., Bogdahn, U., Curschmann, J., Janzer, R.C., Ludwin, S.K., Gorlia, T., Allgeier, A., Lacombe, D., Cairncross, J.G., Eisenhauer, E., Mirimanoff, R.O., Groups, E.O.f.R.a.T.o.C.B.T.a.R., Group, N.C.I.o.C.C.T., 2005. Radiotherapy plus concomitant and adjuvant temozolomide for glioblastoma. The New England Journal of Medicine. 352, 987-996.

Sun, M.Z., Oh, M.C., Ivan, M.E., Kaur, G., Safaee, M., Kim, J.M., Phillips, J.J., Auguste, K.I., Parsa, A.T., 2014. Current management of choroid plexus carcinomas. Neurosurgical Review. 37, 179-192; discussion 192.

Sun, S., Lee, D., Ho, A.S.W., Pu, J.K.S., Zhang, X.Q., Lee, N.P., Day, P.J.R., Lui, W.M., Fung, C.F., Leung, G.K.K., 2013. Inhibition of prolyl 4-hydroxylase, beta polypeptide $(\mathrm{P} 4 \mathrm{HB})$ attenuates temozolomide resistance in malignant glioma via the endoplasmic reticulum stress response (ERSR) pathways. Neuro-Oncology. 15, 562-577.

Tabuchi, K., Yamada, O., Nishimoto, A., 1973. The ultrastructure of pinealomas. Acta Neuropathologica. 24, 117-127.

Tam, A.B., Koong, A.C., Niwa, M., 2014. Ire1 has distinct catalytic mechanisms for XBP1/HAC1 splicing and RIDD. Cell Rep. 9, 850-8.

Tang, J., Guo, Y.S., Zhang, Y., Yu, X.L., Li, L., Huang, W., Li, Y., Chen, B., Jiang, J.L., Chen, Z.N., 2012. CD147 induces UPR to inhibit apoptosis and chemosensitivity by increasing the transcription of Bip in hepatocellular carcinoma. Cell Death Differ. 19, 1779-90.

Tani, E., Higashi, N., 1973. Intercisternal structures of closely arranged endoplasmic reticulum in human meningioma. Acta Neuropathologica. 23, 291-299. 
Tirasophon, W., Welihinda, A.A., Kaufman, R.J., 1998. A stress response pathway from the endoplasmic reticulum to the nucleus requires a novel bifunctional protein kinase/endoribonuclease (Ire1p) in mammalian cells. Genes Dev. 12, 1812-24.

Tsai, H.Y., Yang, Y.F., Wu, A.T., Yang, C.J., Liu, Y.P., Jan, Y.H., Lee, C.H., Hsiao, Y.W., Yeh, C.T., Shen, C.N., Lu, P.J., Huang, M.S., Hsiao, M., 2013. Endoplasmic reticulum ribosome-binding protein 1 (RRBP1) overexpression is frequently found in lung cancer patients and alleviates intracellular stress-induced apoptosis through the enhancement of GRP78. Oncogene. 32, 4921-31.

Ulianich, L., Garbi, C., Treglia, A.S., Punzi, D., Miele, C., Raciti, G.A., Beguinot, F., Consiglio, E., Di Jeso, B., 2008. ER stress is associated with dedifferentiation and an epithelialto-mesenchymal transition-like phenotype in PC Cl3 thyroid cells. J Cell Sci. 121, 477-86.

Upton, J.P., Wang, L., Han, D., Wang, E.S., Huskey, N.E., Lim, L., Truitt, M., McManus, M.T., Ruggero, D., Goga, A., Papa, F.R., Oakes, S.A., 2012. IRE1alpha cleaves select microRNAs during ER stress to derepress translation of proapoptotic Caspase-2. Science. 338, 818-22.

Vermeulen, L., Snippert, H.J., 2014. Stem cell dynamics in homeostasis and cancer of the intestine. Nat Rev Cancer. 14, 468-80.

Wang, Z.V., Deng, Y., Gao, N., Pedrozo, Z., Li, D.L., Morales, C.R., Criollo, A., Luo, X., Tan, W., Jiang, N., Lehrman, M.A., Rothermel, B.A., Lee, A.H., Lavandero, S., Mammen, P.P., Ferdous, A., Gillette, T.G., Scherer, P.E., Hill, J.A., 2014. Spliced X-box binding protein 1 couples the unfolded protein response to hexosamine biosynthetic pathway. Cell. 156, 1179-92.

Weller, M., Wick, W., Aldape, K., Brada, M., Berger, M., Pfister, S.M., Nishikawa, R., Rosenthal, M., Wen, P.Y., Stupp, R., Reifenberger, G., 2015. Glioma. Nature Reviews Disease Primers. 15017.

Yaari-Stark, S., Shaked, M., Nevo-Caspi, Y., Jacob-Hircsh, J., Shamir, R., Rechavi, G., Kloog, Y., 2010. Ras inhibits endoplasmic reticulum stress in human cancer cells with amplified Myc. International Journal of Cancer. Journal International Du Cancer. 126, 2268-2281.

Yacoub, A., Hamed, H.A., Allegood, J., Mitchell, C., Spiegel, S., Lesniak, M.S., Ogretmen, B., Dash, R., Sarkar, D., Broaddus, W.C., Grant, S., Curiel, D.T., Fisher, P.B., Dent, P., 2010. PERK-dependent regulation of ceramide synthase 6 and thioredoxin play a key role in mda-7/IL-24-induced killing of primary human glioblastoma multiforme cells. Cancer Res. 70, 1120-9.

Yamamoto, K., Sato, T., Matsui, T., Sato, M., Okada, T., Yoshida, H., Harada, A., Mori, K., 2007. Transcriptional induction of mammalian ER quality control proteins is mediated by single or combined action of ATF6alpha and XBP1. Dev Cell. 13, 365-76.

Ye, J., Koumenis, C., 2009. ATF4, an ER stress and hypoxia-inducible transcription factor and its potential role in hypoxia tolerance and tumorigenesis. Curr Mol Med. 9, 411-6. 
Table 1: Clinical evidences of UPR involvement in solid cancers

$\left(^{*}\right)$ AA: anaplasic astrocytoma; CRC: colorectal cancer; GBM: glioblastoma; HCC: hepatocellular carcinoma; NSCLC: non-small cell lung cancer; ODG: oligodendroglioma; PAC: prostate adenocarcinoma; PDAC: pancreatic ductal adenocarcinoma ; RCC: renal cell carcinoma ; IDC : invasive ductal carcinoma. (1) calreticulin+, CHOP/GADD153+, ERp72+, GRP94+, GRP170+. (2) CHOP+, GADD34+, GRP94+, SERP1+. (3) ATF4+, ERp72+, PERK+, SERP1+.

\begin{tabular}{|c|c|c|c|c|c|c|c|c|c|c|}
\hline $\begin{array}{l}\text { Tissue of } \\
\text { Origin }\end{array}$ & Cancer $^{(*)}$ & Methods & $\frac{n}{m}$ & 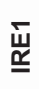 & $\frac{\bar{n}}{\dot{m}}$ & $\frac{\frac{n}{0}}{\frac{n}{x}}$ & 兑 & $\begin{array}{l}\text { 용 } \\
\frac{1}{\sigma}\end{array}$ & 这 & Reference \\
\hline \multirow[t]{3}{*}{ Brain } & GBM & $\mathrm{IHC}, \mathrm{WB}$ & + & & + & + & + & & (1) & (Epple et al., 2013) \\
\hline & GBM & WB & + & & & & & & & (Pyrko et al., 2007) \\
\hline & GBM, AAIII, AAII, ODG & Transcriptomic, IHC, WB & + & & & & & & & (Lee et al., 2008) \\
\hline \multirow[t]{4}{*}{ Breast } & invasive (stages II \& III) & $\mathrm{IHC}$ & + & & & & & & & (Lee et al., 2006) \\
\hline & ductal, lobular, stages II \& III & $\mathrm{NB}, \mathrm{IHC}, \mathrm{WB}$ & + & & & & & & & (Fernandez et al., 2000) \\
\hline & Adenocarcinoma & $\mathrm{IHC}$ & + & & + & & & & & (Scriven et al., 2009) \\
\hline & $E R \alpha+I D C$ & Transcriptomic & + & & + & 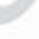 & + & + & (2) & (Andruska et al., 2015) \\
\hline Colorectal & stages II \& III CRC & $\mathrm{IHC}$ & + & & P & & & & & (Mhaidat et al., 2015) \\
\hline & adenoma, CRC & RT-PCR, IHC & & & + & & & & & (Fujimoto et al., 2007) \\
\hline Kidney & RCC (stages I to IV) & Q-PCR, IHC & + & & & & & & & (Fu et al., 2010) \\
\hline Liver & $\mathrm{HCC}$ & $\mathrm{IHC}$ & + & & & & & & & (Al-Rawashdeh et al., 2010) \\
\hline & $\mathrm{HCC}$ & NB, Q-PCR, IHC & + & & + & + & + & & & (Shuda et al., 2003) \\
\hline & $\mathrm{HCC}$ & $\mathrm{IHC}$ & + & & & & & & & (Tang et al., 2012) \\
\hline Lung & NSCLC & $\mathrm{IHC}$ & + & & & & & & & (Tsai et al., 2013) \\
\hline Pancreas & PDAC & $\mathrm{IHC}$ & + & & & & & & & (Niu et al., 2015) \\
\hline Prostate & PAC & Transcriptomic, IHC & + & + & & + & + & + & (3) & (Sheng et al., 2015) \\
\hline
\end{tabular}


Table 2: Experimental evidence for UPR involvement in primary brain tumors

\begin{tabular}{|c|c|c|c|}
\hline Tumor type & Structural and signaling features & Models & References \\
\hline \multicolumn{4}{|l|}{ Glioblastoma } \\
\hline Ultrastructure & - Distended endoplasmic reticulum & Human & (Liberski, 1998) \\
\hline IRE1 & $\begin{array}{l}\text { - Regulation of vascularization through EGFR, VEGF-A, IL-1, IL-6 and } \\
\text { IL-8; control of vessel co-option } \\
\text { - Control of infiltration, migration and immune infiltrate } \\
\text { - Regulation of PER1 expression (circadian clock gene) }\end{array}$ & U87 & $\begin{array}{l}\text { (Auf et al., 2010b; Auf et al., } \\
\text { 2013; Dejeans et al., 2012; } \\
\text { Jabouille et al., 2015; Pluquet et } \\
\text { al., 2013a) }\end{array}$ \\
\hline ATF6 & $\begin{array}{l}\text { - Increased expression following ionizing radiation } \\
\text { - Role in cell proliferation and death in response to ionizing radiation } \\
\text { - Regulation of NOTCH1 gene expression }\end{array}$ & $\begin{array}{l}\text { LN428 } \\
\text { LN427 } \\
\text { D54 }\end{array}$ & (Dadey et al., 2015) \\
\hline PERK & $\begin{array}{l}\text { - Increased expression following ionizing radiation } \\
\text { - Role in TMZ resistance through P4HB } \\
\text { - Role in metabolism control }\end{array}$ & D54 & $\begin{array}{l}\text { (Sun et al., 2013) } \\
\text { (Hou et al., 2015) }\end{array}$ \\
\hline $\begin{array}{l}\text { Effectors (GRP94, } \\
\text { GRP78, XBP-1, } \\
\text { CHOP, other } \\
\text { chaperones) }\end{array}$ & $\begin{array}{l}\text { - Global upregulation in glioma cells, especially GRP78 } \\
\text { - Upregulation of GRP78/GRP94/XPB-1s \& TMZ chemoresistance } \\
\text { - Caspases induction dependent on GRP78 expression } \\
\text { - GRP78 expression correlates with MT1-MMP maturation } \\
\text { - ORP150-mediated angiogenesis through VEGF } \\
\text { - Lower CHOP induction in GBM cells }\end{array}$ & $\begin{array}{l}\text { U87 } \\
\text { U118 } \\
\text { LN229 } \\
\text { C6 } \\
\text { A172 } \\
\text { U373 }\end{array}$ & $\begin{array}{l}\text { (Epple et al., 2013) (Pyrko et al., } \\
2007 \text { ) } \\
\text { (Johnson et al., 2014) } \\
\text { (Lee et al., 2008) } \\
\text { (Quick and Faison, 2012) } \\
\text { (Proulx-Bonneau et al., 2011) } \\
\text { (Ozawa et al., 2001) }\end{array}$ \\
\hline Other pathways & $\begin{array}{l}\text { - Cell death signaling by cyclophilin B through ER stress pathways } \\
\text { - Regulation of CHOP/GADD153 and GRP78 by Galectin-1 }\end{array}$ & $\begin{array}{l}\text { U251 } \\
\text { Hs683 }\end{array}$ & $\begin{array}{l}\text { (Choi et al., 2014) } \\
\text { (Le Mercier et al., 2008a; Le } \\
\text { Mercier et al., 2008b) }\end{array}$ \\
\hline \multicolumn{4}{|l|}{ Other astrocytomas } \\
\hline Ultrastructure & - Occasional ER distension in oligodendrogliomas & Human & (Liberski, 1996) \\
\hline GRP78 & - Low expression in lower-grade astrocytomas & $\begin{array}{l}\text { Human } \\
\text { A172 } \\
\text { U87 } \\
\text { LNZ308 } \\
\text { U251 } \\
\text { LN-443 } \\
\text { LN-229 }\end{array}$ & (Lee et al., 2008) \\
\hline \multicolumn{4}{|l|}{ Meningiomas } \\
\hline Ultrastructure & - Abundant rough ER depending on meningioma type & Human & $\begin{array}{l}\text { (Tani and Higashi, 1973) } \\
\text { (Couce et al., 2000) }\end{array}$ \\
\hline ATF6 & $\begin{array}{l}\text { - Single nucleotide polymorphisms associated of ATF6 gene } \\
\text { associated with aggressive phenotype }\end{array}$ & Human & $\begin{array}{l}\text { (Iglesias Gómez and Mosquera } \\
\text { Orgueira, 2014) }\end{array}$ \\
\hline Other features & - Localization of antigen TXNDC16 within the ER & $\begin{array}{l}\text { BenMen1 } \\
\text { HBL52 } \\
\text { IOMM-Lee }\end{array}$ & (Harz et al., 2014) \\
\hline \multicolumn{4}{|l|}{ Medulloblastomas } \\
\hline PERK & $\begin{array}{l}\text { - Promotion of cell migration through VEGF-A } \\
\text { - Activation in SHH-type, IFN gamma induced medulloblastoma }\end{array}$ & $\begin{array}{l}\text { Daoy } \\
\text { UW228 }\end{array}$ & $\begin{array}{l}\text { (Jamison et al., 2015) } \\
\text { (Lin et al., 2011) }\end{array}$ \\
\hline \multicolumn{4}{|l|}{ Pineal tumors } \\
\hline Ultrastructure & $\begin{array}{l}\text { - Abundant rER in pinealoblastomas, papillary tumors and } \\
\text { pinealocytomas }\end{array}$ & Human & $\begin{array}{l}\text { (Kline et al., 1979) } \\
\text { (Jouvet et al., 2003) } \\
\text { (Tabuchi et al., 1973) }\end{array}$ \\
\hline $\begin{array}{l}\text { Choroid tumors } \\
\text { Ultrastructure }\end{array}$ & - Hypertrophied endoplasmic reticulum in choroid plexus carcinoma & Human & $\begin{array}{l}\text { (McComb and Burger, 1983) } \\
\text { (Anguilar et al., 1983) }\end{array}$ \\
\hline SERCA3 & - Decrease of expression in papillomas, absent in carcinomas & & (Ait-Ghezali et al., 2014) \\
\hline
\end{tabular}


Figures legends

Figure 1: The UPR sensors and their downstream signals. During ER stress, GRP78 is released from IRE1 $\alpha$, PERK and ATF6 sensors allowing their dimerization/oligomerization or export to the Golgi apparatus. PERK activation leads to phosphorylation of NRF2 and elF2 $\alpha$. Phosphorylation of elF2 $\alpha$ induces global translation attenuation and increases that of AFT4. ATF4 and NRF2 induce expression of genes involved in antioxidant response, protein folding, amino acid metabolism, autophagy and apoptosis. The negative feedback loop activated downstream of PERK dephosphorylates elF2 $\alpha$ to restore translation. IRE1 $\alpha$ activation leads to JNK phosphorylation, RIDD activity and XBP1 splicing that induces expression of genes involved protein folding, secretion, ERAD and lipid synthesis. Activation of ATF6 leads to its export in the Golgi apparatus where its cytosolic domain is released to translocate to the nucleus and activate the transcription of genes involved in protein folding and ERAD. Antioxyd: antioxidant response; Lipid synth: lipid synthesis; QC: quality control.

Figure 2: UPR signals in primary brain cancers and biological outcomes. UPR signals downstream of IRE1 $\alpha$, PERK and ATF6, and the subsequent biological outcomes of such signaling pathways in the different tumors described in the manuscript.

Figure 3: Expression of ATF6, PERK and IRE1 in normal brain, astrocytes and in the different stages of glioma (WHO Grade II to IV). Gene expression profiles from GDS1815, GDS1962, GDS1975, GDS2853, GDS3069, GDS4467 and GDS4465 datasets (including normal brain tissues $(n=25)$, astrocytes $(n=3)$, grade II $(n=64)$, grade III $(n=84)$ and grade IV $(n=251)$ brain tumors) were collected from the GEOPROFILE database and the expression levels of PERK, IRE1 and ATF6 were analyzed. (FI stands for fluorescence intensity).

Highlights

* The UPR plays essential roles in brain tumor development

* ER proteostasis is altered in various primary brain tumors

* ER proteostasis adaptation impacts on tumor characteristics 

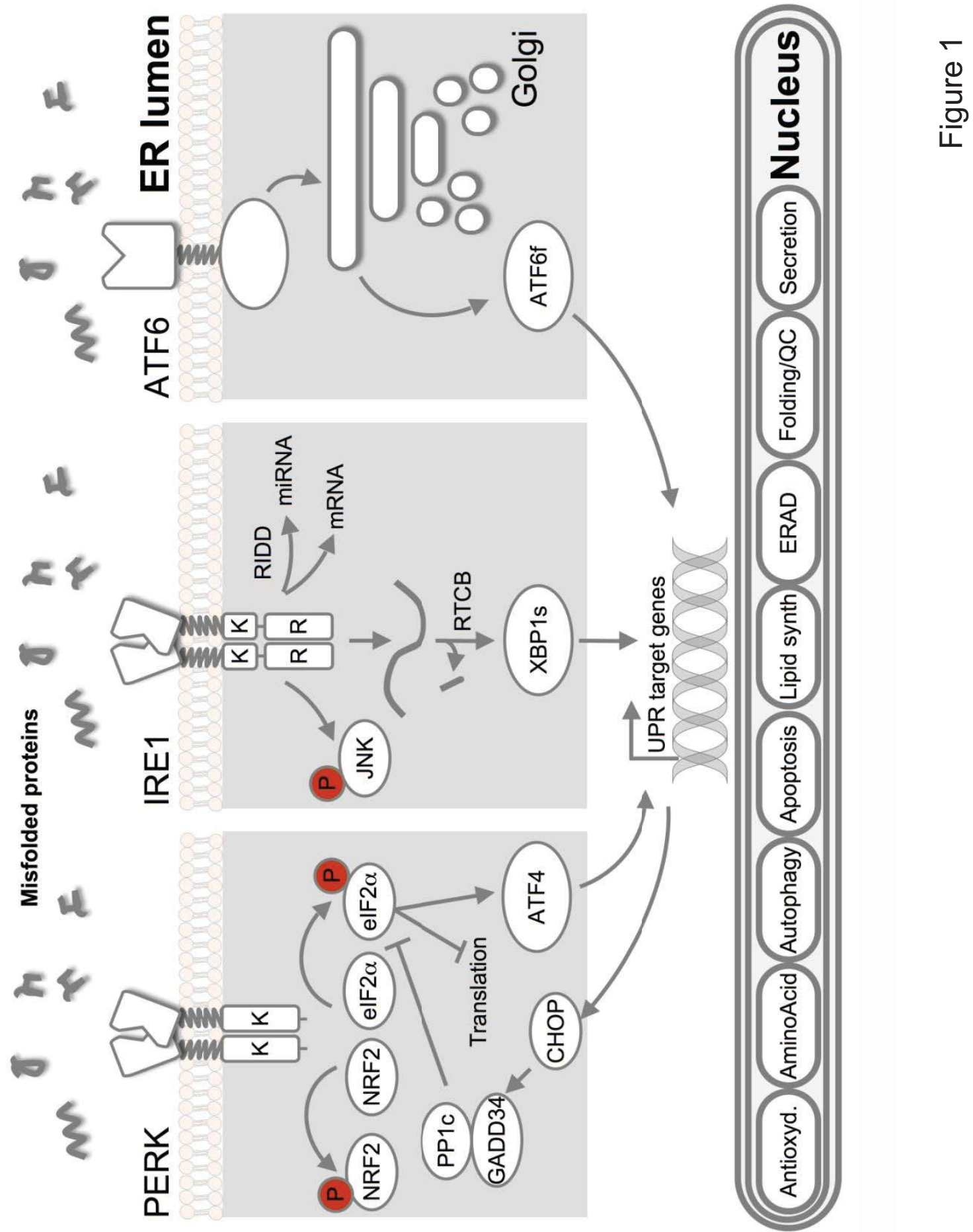

논 

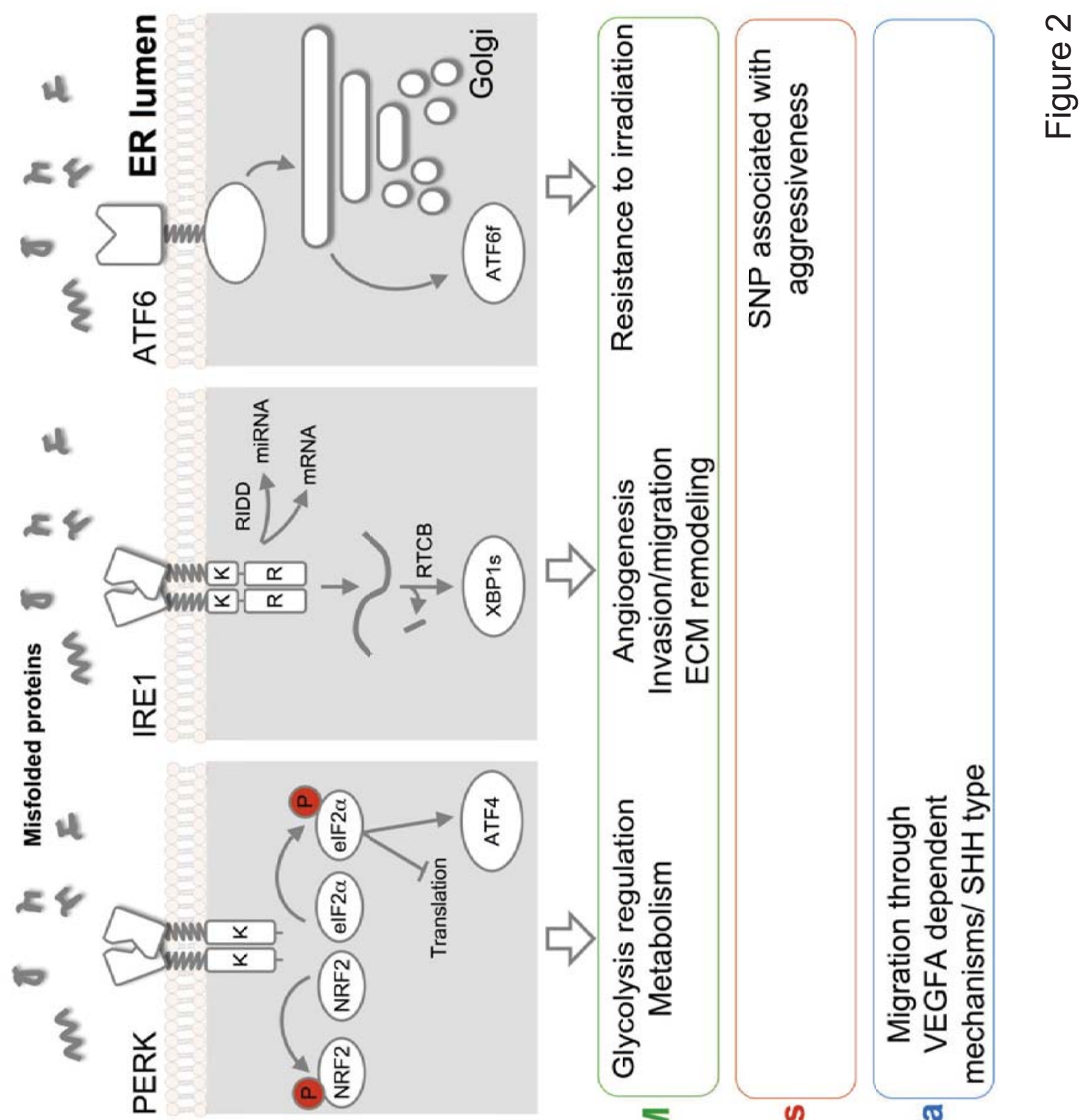

兽

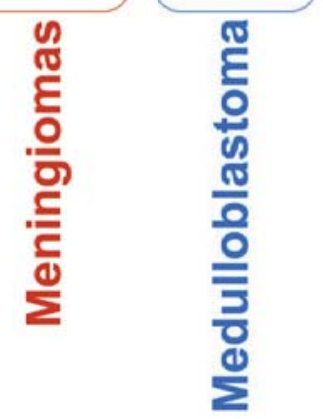



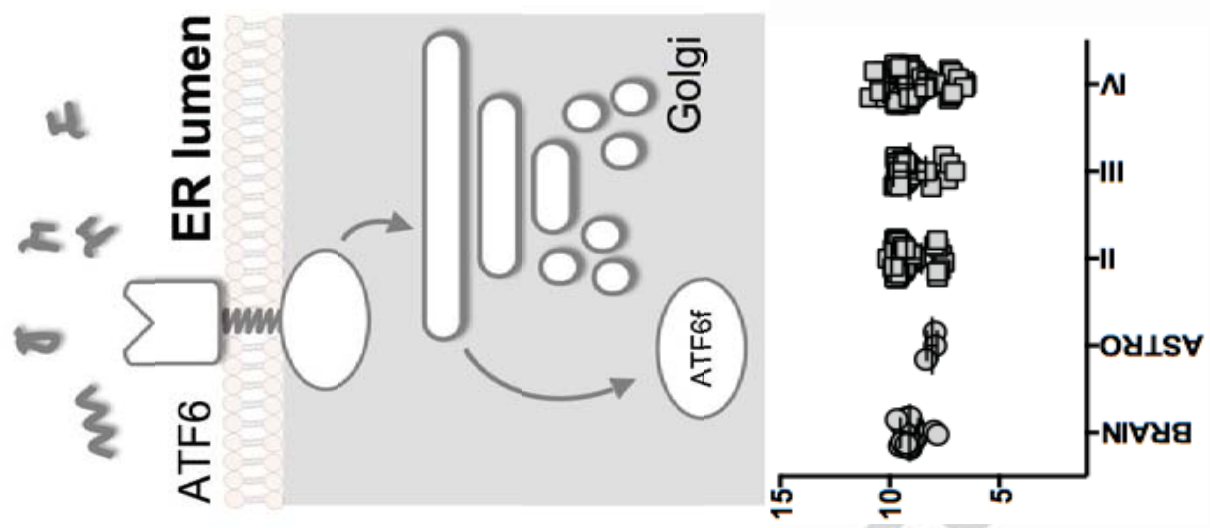

$m$
$\frac{0}{5}$
$\frac{5}{2}$
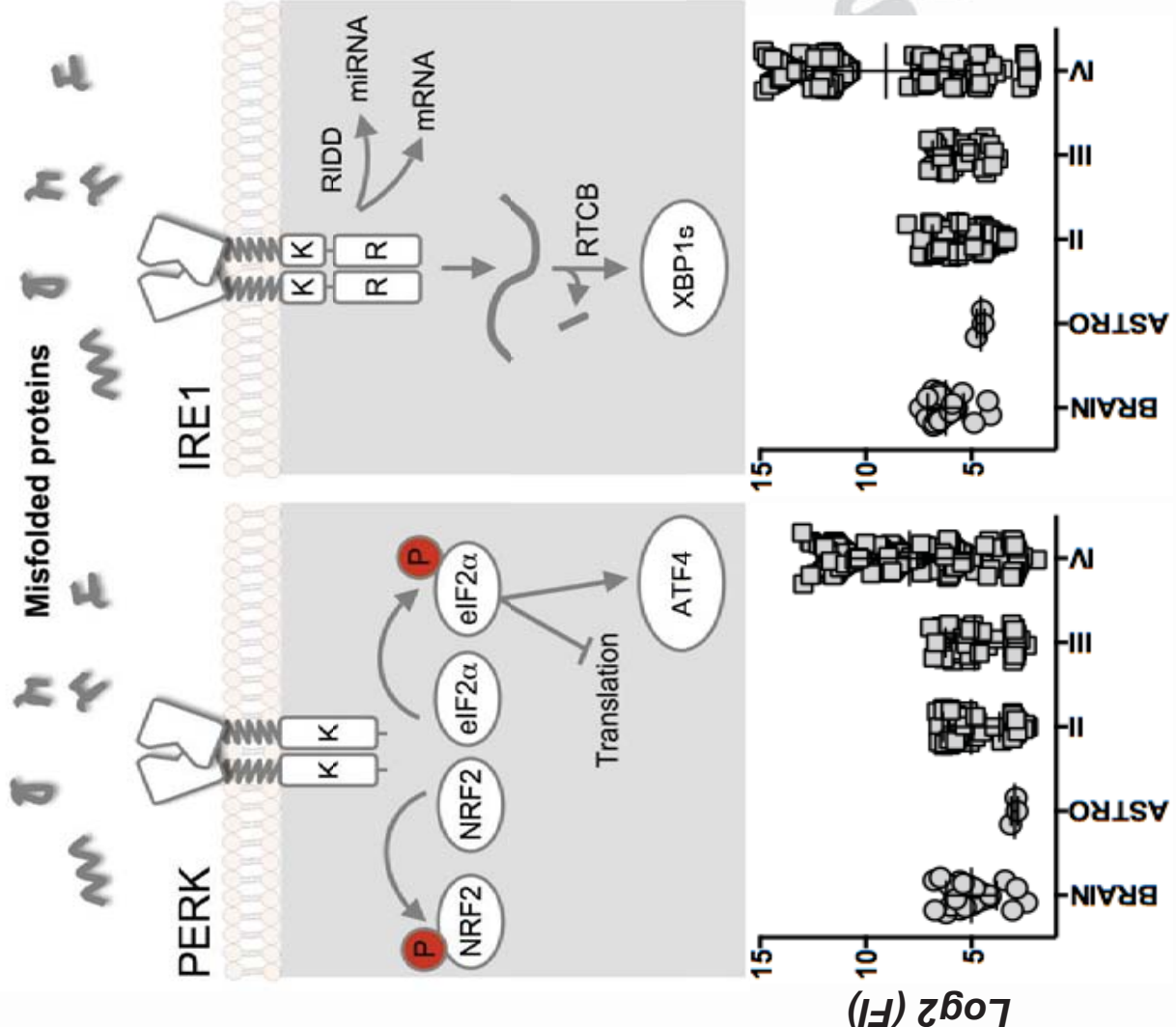